\title{
A REEXAMINATION OF WILLIAM COBBETT'S OPINIONS \\ OF THOMAS PAINE
}

\author{
BY CLARIBEL YOUNG
}

Mrs. Young is a graduate student in history at Rutgers University

$I^{\prime}$ $\mathrm{N}$ I 8 I7, William Cobbett, then at the height of his influence as a publisher and proponent of political reform, made his second trip to the United States. He voluntarily exiled himself in order to avoid what he felt would be certain prosecution following the passage of the "gagging" acts aimed at silencing critics of the Liverpool ministry. Cobbett's Political Register, published from I 802 to I 835 , was a popular paper which more and more called for reform of the governmental "system" which he had come to regard as corrupt and repressive. Before returning to his homeland in $18 \mathrm{I} 9$, he disinterred the body of Thomas Paine and shipped it to England where he was unsuccessful in his attempt to raise money for a lasting memorial.

By examining Cobbett's puzzling personality through the narrow topic of his lifelong preoccupation with Paine, ${ }^{1}$ some insight may be gained which will dispel the erroneous conclusion that Cobbett was moved by sincere feelings of devotion and respect for "Old Common Sense."

William Cobbett and Thomas Paine were contemporaries, both of whom became renowned for their expertise as pamphleteers. There is no evidence that they ever corresponded, and they certainly never met though they were in England and France at the same time for brief periods from November of I 79I to September of I 792. ${ }^{2}$ They were both born in England; Cobbett the son of a tavern-keeper in Surrey; and Paine the son of a staymaker in Norfolk. Both died at the age of 72. Their lives became curiously intertwined by the times

${ }^{1}$ John W. Osborne, William Cobbett: His Thought and His Times (New Brunswick, I 966), p. x. Osborne says, "Perhaps the combination of mental rigidity, disorganized thought and very flexible tactics accounts in part for the many varying (and usually inaccurate) interpretations of his life's work. The nature of the latter becomes clearer when Cobbett's ideas are examined topically."

2 They were of course both in England from the time of Cobbett's birth in 1763 until Paine's emigration to America in 1774 . 
in which they lived and the manner in which they reacted to the events of an era marked by extreme changes in attitudes concerning government, human rights, and religion.

Paine had achieved a level of eminence in pamphleteering long before Cobbett entered that profession. Paine might properly be designated as belonging to the generation of men who preceded Cobbett: eighteenth century political philosophers who laid the revolutionary groundwork for nineteenth century political reform. Paine's writing had a profound influence on these later political thinkers. However, his early popularity slipped into disrepute as his life, work, and principles came under attack.

In only a few instances does Cobbett appear to be mentioned in Paine's correspondence. ${ }^{3}$ An examination of Cobbett's political works, on the other hand, reveals continuous reference to Paine. Paine's limited interest in Cobbett is natural inasmuch as Cobbett outlived Paine by more than twenty-five years. Still, during Paine's lifetime, Cobbett made him the target of his acid pen on many occasions. Yet Paine forebore to acknowledge publicly Cobbett's existence.

Paine appears as a positive force early in Cobbett's life. Following his discharge from the army in December of I79I, William Cobbett married, charged his regimental officers with corruption and fled to France with his bride when it became apparent that he could not win his case at their court martial trial although he believed he possessed

${ }^{3}$ I could locate but two direct references to Cobbett in Paine's work and a third which I think pertains. Of course, much of Paine's correspondence was lost in a St. Louis fire which destroyed materials which had been stored by Madame Bonneville following her move to that city.

Thomas Paine, "A Letter to General. Washington 1796" in Mary Elizabeth Clark, Peter Porcupine in America, The Career of William Cobbett 1792-1800 (Philadelphia, 1939), p. 77. (This was the famous letter published in Bache's Aurora which Cobbett answered in "A Letter to the Infamous Tom Paine." See below.) Paine said, "I know not who the writer of the piece is; but some late Americans say it is Phineas Bond, an American refugee, and now a British Consul; and that he writes under the signature of Peter Skunk, or Peter Porcupine, or some such signature. . .."

Thomas Paine in "To the Citizens of the United States and Particularly to the Leader of the Federal Faction" which was originally printed in the National Intelligencer (1802-1803) and appears in John Dos Passos, The Living Thoughts of Tom Paine (New Haven, 196I), p. I5I. "There is in America more than in any other country, a large body of people who attend quietly to their farms, or follow their several occupations; who pay no regard to the clamors of anonymous scribblers, who think for themselves, and judge of government, not by the fury of newspaper writers, but by the prudent frugality of its measures, and the encouragement it gives to the improvement and prosperity of the country. ... When this body moves, all the little barkings of scribblers and witless curs pass for nothing."

Letter from Thomas Paine to Mr. Hyer, March 24, 1804 , in Moncure Daniel Conway, The Life of Thomas Paine, Vol. II, 3rd ed. (New York, 1908), p. 336. "Peter Porcupine, I see, is become the panegyrist of Bonaparte." 
the evidence of their guilt. He arrived in March of $\mathrm{I} 792$ and left for America in October of that year to avoid the violence occasioned by Louis' downfall.

Cobbett described the feelings which prompted his actions at that time.

Let it be considered that I had just arrived in England; that I was a perfect novice in politics, never having, to my recollection, read even a newspaper while abroad ${ }^{4}$ and, let it be considered, too, that I took up the book of Paine (just then published) [Rights of Man Part I] with my mind full of the indignation at the abuses which I myself had witnessed. . . . Previous to my leaving England for France, previous to my seeing what republicanism was, I had not only imbibed its principles, I had not only been a republican, but an admirer of the writings of Paine. ${ }^{5}$

Mary Elizabeth Clark commented on Cobbett's disaffection with English government at this period of his life in Peter Porcupine in America.

When Cobbett saw that his attempt to reform the army system was hopeless and that he would merely be a useless martyr to a vain cause if he persisted farther, he decided to leave England altogether, disgusted with a governmental system under which such conditions could exist. In this frame of mind it is not surprising that the attraction of republicanism and an enthusiasm for its principles...

led Cobbett to the United States. ${ }^{6}$

Cobbett arrived armed with an introductory letter to Thomas Jefferson, whom he pressed for employment, stating, "Ambitious to become the Citizen of a free state, I have left my native country, England, for America." No opening being available, Cobbett employed himself as an English tutor to French emigrés.

While Cobbett was fleeing the French Revolution in I 792 to take up residence in the young American republic, Paine had fled England for France in order to avoid prosecution for his politically inflammatory pamphlet, Rights of Man Part II. Invited to take a seat

\footnotetext{
${ }^{4}$ Cobbett's reference here to being abroad, refers to his sojourn in Canada while in the army.

${ }^{5}$ William Cobbett, The Autobiography of William Cobbett, The Progress of a PloughBoy to a Seat in Parliament, ed. William Reitzel (London, 1933), p. 53.

${ }^{6}$ Clark, p. 4.

${ }^{7}$ Cobbett, in Clark, p. 7 .
} 
in the French National Assembly, Paine participated in the formation of the new republic but was imprisoned by Robespierre when he voted for exile rather than death for Louis XVI. The excesses of the revolution turned popular opinion in England against Paine. And the publication of Age of Reason caused many American followers to look with disfavor upon his Deistic precepts. In the turmoil of the late eighteenth and early nineteenth centuries, the American government was trying to maintain a delicate balance in European politics, and Paine's involvement in France became an embarrassment to the administrations of Washington and Adams.

Cobbett became a pamphleteer in Philadelphia in I 794 after publication of his "Observations on the Emigration of Dr. Priestley," in which he vigorously defended the British government against Jacobin attacks. It is not clear whether he had become disaffected with republican government per se at this time; or whether, stung by the violent attacks on his homeland, he took the patriotic but unpopular position of defending the British in America. Cobbett's vitriolic style, sprinkled with wit and pointed humor made him an instant success and he continued writing for Thomas Bradford's Political Censor until I 796 when he split with Bradford, referring to the publisher's son as ". . . this hatter turned printer, this sooty-fisted son of ink and urine, whose heart is as black and as foul as the liquid in which he dabbles. ..."

This was not an unusually acerbic attack for Cobbett. It is typical of the style he developed which studs his work with alliteration, allegory, denunciation and humiliation. It is humorous, witty and appellative. He adopted Peter Porcupine as a pen name early in his career as a result of a comparison drawn by a journalistic competitor.

His method, even in defense, was offense, in both definitions of the word. No matter what the issue, however, he usually reduced it to a personal level. As has been observed, “. . . his partisanship and concern for events and personalities rather than ideas ..." were the hallmarks of his direct style. ${ }^{9}$ Yet in his defense it should be noted that the objects of his pen were not usually defenseless targets, but strong, able and established opponents whose answers to his attacks supplied energetic and lively discourses for readers of the popular

\footnotetext{
${ }^{8}$ Cobbett, in Robert Huish, Memoirs of the Late William Cobbett, Esq., Vol. I (London, 1836 ), p. 135 .

${ }^{9}$ Osborne, p. 20.
} 
press. Not always deterred by adherence to truth, fact, or accuracy, he struck out at his enemies with passion and anger.

Paine was by no means the only target of his quill. But Paine was a subject which he dealt with in both periods of his journalistic career-American (I794-I800) as a Tory; and England (I 800I 835 ) as a "utopian reactionary." ${ }^{10}$ During his formative years as a writer in America, he generally defended England, the American federal government, established religion, and himself and his work. He attacked republicanism, Jacobins, personalities, and avowed enemies.

In May of 1796, Cobbett published in the Political Censor a scathing indictment of Paine, his recently published Age of Reason, and Franklin Bache who was offering it for sale. ${ }^{11}$

... The papers have told us lately, that Mad Tom takes up his lodgings at the house of the American Ambassador [Monroe ]; if this second part of the Age of Reason should have come to us under his [Monroe's] auspices, it is a fact of a curious nature indeed. . . . How Tom came to think of exercising his clumsy pen upon the Christian Religion is what has excited a good deal of curiosity. . . . For this reason I shall endeavor to trace this raggamuffin deist from America to his Paris dungeon, and to account for his having laid down the dagger of insurrection in order to take up the chalice of irreligion. ${ }^{22}$

At this point, Cobbett proceeded to revile Paine's life. (These same passages were exhumed seven months later to fatten his unfair "Life of Thomas Paine" under the authorship of Peter Porcupine.) But though Cobbett admitted he was aware in May of I 796 that Paine, "the demi-god" and "most degraded thing in nature," was alive in Paris, a letter presumably submitted by a Boston reader, was added anonymously.

${ }^{10}$ Ibid., p. 254. Osborne has defined Cobbett's position in the political spectrum. "Perhaps if a label is desired, utopian reactionary is as close as one might come to identifying Cobbett in a word or two. Reactionary because his ideal was fixed in the past, utopian because it was visionary, basically a product of his imagination. For all his gibes at the dreamers of his day, Cobbett himself was thoroughly romantic. He was certainly not radical; nor was he conservative, if that much-abused term means a devotion to the preservation of established institutions."

${ }^{11}$ Cobbett, Political Censor, May i 796, p. 206.

12 Ibid., pp. I $97-198$. 
Sir, ... I presume that the report concerning Paine can be no reason for delaying the publication of his Epitaph. He has long since given up the ghost as a politician; of this our present incertitude respecting his natural death, is a clear, and for him, humiliating proof: who would once have thought that the time would come when it would be unknown whether the great Rights of Man was in existence or not? Being then assured that he is politically dead, it is of little consequence, whether his person has survived his fame, whether his carcass be under ground, or whether it be reeling about among the cut-throat philosophers of Paris. ... ${ }^{13}$

It is significant in view of the questionable authorship of this letter and the Epitaph that follows, that Cobbett used Rights of Man synonymously with Paine. The Epitaph is probably Cobbett's as well. ${ }^{14}$ A portion reads:

... Here he murders and thieves and makes

laws for a season;

Is cramm'd in a dungeon, and preaches up

Reason;

Blasphemes the Almighty, lives in filth

like a hog,

Is abandon'd in death, and interr'd like

a dog....

And at last to the sorrow of all the beholders,

He march'd out of life with his head on

his shoulders. ${ }^{15}$

Cobbett's phraseology and imagery are easily discernible. There can be little doubt that he anticipated Paine's death with relish and in this early effort he buried him politically.

Cobbett's attack on Paine in the "Life of Thomas Paine, interspersed with remarks and reflections" was based on Oldys' disreputable biography published in England in $1793 .{ }^{16}$ In Cobbett's

${ }^{13}$ Ibid., p. 207.

${ }^{14}$ In the original pamphlet published in May of 1796 , Cobbett ascribes the epitaph to an anonymous Boston reader and encloses it in quotation marks. But in the twelve volume collection of Porcupine's Works, published by Cobbett in $180 \mathrm{r}$ in London, the letter and reference to the donor is omitted and the epitaph is printed as Cobbett's work.

${ }^{15}$ Ibid., p. 209.

${ }^{16}$ David Freeman Hawke, Paine (New York, 1974), p. 231. Hawke gives a good capsulized explanation of "Oldys" " handiwork. "The biography of 'Francis Oldys' was harder to take for one as secretive of his personal life as Paine. 'Oldys' was a pseudonym 
rendition of the work published in September I796, "Paine was accused of almost every crime in the calendar, his private equally with his public life being traversed with scant regard to facts." ${ }^{17}$ With his usual invective, Cobbett used sarcasm to introduce the reasons for his publication of the biography.

I am afraid it will be a lasting reproach on those, into whose hands this press has fallen, that while thousands upon thousands of that blasphemous work, "the Age of Reason," were struck off, the instant it arrived in the country, not a single copy of the Life and Crimes of the Blasphemer, so fit to counteract his diabolical efforts, was printed in the whole union. ${ }^{18}$

It is unnecessary here to discuss the many errors and falsifications of the work long disproven by the competent scholarship of Moncure Daniel Conway, Paine's earliest factual biographer. But it should be noted that Cobbett's popularity coupled with the many biographies of Paine written afterwards and in part based on Oldys' pamphlet, delayed and obscured the writing of a more laudatory work, a problem with which Conway had to deal. ${ }^{19}$ Cobbett's view of Paine as the "scoundrel of a staymaker," "hypocritical monster," "traitor," and "discarded English exciseman," appears throughout the sixty-page work.

Paine had languished in the Luxembourg prison from December of 1792 to November of 1793 with the threat of the guillotine ever present, seemingly deserted by the American minister, Gouverneur

for George Chalmers, a Scots lawyer who had emigrated to Maryland then on the eve of independence returned to England, a venomous foe of all politicians friendly toward the colonies. He attacked Burke first in a pamphlet in 1777 and five years later published another on The Deformities of Fox and Burke. He worked for the Board of Trade, and though Paine and his friends dismissed him as a mere clerk he was more than that. He had achieved a measure of fame with his Estimate of the Comparative Strength of Great Britain, a reliable compendium of facts. ... He had written a book on Shakespeare ... and ... Daniel Defoe.... . The government subsidized Chalmers to dig into Paine's past. He did the job so well that virtually everything known about the first thirty-seven years of Paine's life stems from his research."

${ }_{17}$ G.D.H. Cole, The Life of William Cobbett, 3 rd ed. (London, 1947), p. 6 o.

${ }^{18}$ Cobbett, Political Censor, Sept. 1 796, No. V, in Porcupine's Works, Vol. 4, p. 74.

${ }^{19}$ Conway, Vol. I, Preface to the First Edition, p. xvi. "I recognized the old effigy of Paine elaborately constructed by Oldys and Cheetham, and while writing a paper on the subject (Fortnightly Review, March 19, 1879) discovered that those libels were the only "biographies" of Paine in the London Library. ...."

Conway, Vol. I, Preface to the Third Edition, pp. vii-viii. "I found it impossible to deal with him as an ordinary subject of inquiry. It were vain to try and persuade people to take seriously a man tarred, feathered, pilloried, pelted. It was not white-washing Paine needed, but removal of the pitch, and release from the pillory." 
Morris, and President Washington, to whom he had appealed to intercede on his behalf. ${ }^{20} \mathrm{He}$ was finally freed as a result of the endeavors of James Monroe, who found him near death and nursed him back to health. In the fall of 1793 Paine was a disspirited man (and we know from the Political Censor of May I 796 that Cobbett was aware of his release), yet in December 1796 Cobbett again attacked him in the "Life of Thomas Paine." He wrote:

Let us now turn to the hoary blasphemer at the bottom of his dungeon. There he lies! manacled, besmeared with filth, crawling with vermin, loaded with years and infamy. This, reader, whatever you may think of him, is the author of the Rights of Man, the eulogist of French liberty. The very same man who a few months back boasted of being "the representative of twentyfive millions of free men." Look at him. Do you think now, in your conscience, that he has the appearance of a legislator, a civilian, a constitution maker? It is no tyrannical king, I'll assure you, who has tethered him thus. He was condemned by his colleagues, and his fetters were rivetted by his own dear constituents. Here he is, fairly caught in his own trap, a striking example for the disturbers of mankind. ${ }^{21}$

In view of later events to be dealt with here, the finale of this "biography" takes on a sinister and eerie implication.

He has done all the mischief he can in the world, and whether his carcass is at last to be suffered to rot on the earth, or to be dried in the air, is of very little consequence. Whenever and wherever he breathes his last, he will excite neither sorrow nor compassion; no friendly hand will close his eyes, not a groan will be uttered, not a tear will be shed. Like Judas he will be remembered by posterity; men will learn to express all that is base, malignant, treacherous, unnatural and blasphemous, by the single monosyllable, Paine. ${ }^{22}$

${ }^{20}$ Conway, Vol. II, Chapter X, "The Silence of Washington," in particular, p. 174.

21 Cobbett, Political Censor, December I 796, p. 58-59.

22 Ibid., p. 60. Conway maintains a "Judas Legend" had become attached to Paine's name. $\mathrm{He}$ ascribes its beginnings to an insignificant work. In Appendix I, Vol. II, p. 455, Conway says, "The Rev. Robert Bolton, in his History of Westchester County, . . . says, 'His Paine's body was brought up from New York in a hearse used for carrying the dead to Potter's Field.' " Conway was obviously unaware of the earlier Cobbett reference given here, which may have inspired Bolton. If a Judas Legend had grown up around Paine's name it is most likely as a result of Cobbett's work which reached many more readers than Bolton's later history. 
How Paine reacted to this unbridled attack we will never know. However, his friend Joel Barlow recalled, "You ask what company he kept. He always frequented the best ... till he became the object of calumny in certain American papers for his adherence to what he thought the cause of liberty in France-till he conceived himself neglected and despised by his former friends in the United States. From that moment he gave himself very much to drink, and, consequently, to companions less worthy of his better days." ${ }^{23}$

Paine, embittered over his desertion by Washington, attacked him in a letter published in the United States in I796. Washington was stunned by it, Morris having concealed Paine's true condition. ${ }^{24}$ But Washington read and commented on Cobbett's answer in "Letter to the Infamous Tom Paine" printed by Peter Porcupine in the Spring of I 797. ${ }^{25}$ Cobbett admonished the "Prince of Demagogues": "Your 'private affairs' were long ago public. Every one knew and every honest heart rejoiced, that you had found a Bastille in . . . your 'Palace of Freedom'; that your filthy carcass was wasting in chains, instead of wallowing in the plunder you had promoted." ${ }^{26}$ He vilified Paine for his attacks on Washington's sins of omission, and on his criticism of the American Constitution. Cobbett compared Paine's comments in the open letter, to his arguments in the Rights of Man when he recommended the American Constitution to the British.

There is a pretty poesy for you, Thomas! What a vile wretch you must be! That which was becoming the "admiration of the world," is now "a copy, not quite so base as the original, of the British Government"; and you were exhausting all the hell of sophistry to persuade the English to change their Constitution for another, from which the vices of their own are "naturally to be expected."27

Paine's arguments against the weaknesses of the Constitution included the manner in which Senators were then chosen. ${ }^{28}$ But Cob-

${ }^{23}$ Letter from Joel Barlow to James Cheetham, Aug. I1, 1 809, in Dos Passos, p. 49.

${ }^{24}$ Conway, Vol. II, pp. I73-175.

${ }^{25}$ Letter from George Washington to David Stuart, January 8, 1797, in Conway, Vol. II, p. I 75. “. . . I send you a letter of Mr. Paine to me, printed in this city . . . , and disseminated with great industry. ... Enclosed you will receive also a production of Peter Porcupine, alias William Cobbett. Making allowances for the asperity of an Englishman, for some of his strong and coarse expressions, and a want of official information as to many facts, it is not a bad thing."

${ }^{26}$ Cobbett, Political Censor, January 1 797, p. $6 . \quad 27$ Ibid., p. I 8.

28 At that time U.S. Senators were appointed by state legislatures. Thus, Paine argued, 
bett did not address himself to the validity of this or any other argument. He carried on a polemical discourse comparing Paine's works with his earlier writing. Such comparisons of his own words were to plague Cobbett all his life. ${ }^{29}$ Then Cobbett took him to task even for desiring to save his own life.

Why should you not be included as well as the thousands you assisted in sentencing to death? What poor whimpering story is here! ... Are you not ashamed, Tom! . . Instead of coming forth from your den, a volunteer martyr in this glorious cause, and crying, Viva la Republique! with your neck under the $\mathrm{Na}-$ tional razor, you tremble even now at the thoughts of your danger. Instead of dancing to the music of your republican chains, you pine and peak and cry for Liberty.... ${ }^{30}$

Here, Cobbett was suggesting that Paine should have been happy to die! And Cobbett, obviously, would have been happy to see him so. (Cobbett, imprisoned in I 8 ro under much more agreeable circumstances, issued more copious complaints for less reason.)

In I797, Peter Porcupine, recognizing the threats made against him might lead to violence, and wanting to prepare himself by putting his affairs in order, the prickly fellow wrote a sardonic and humorous will bequeathing a number of items, mostly to his enemies:

In the name of Fun, Amen, I, Peter Porcupine, Pamphleteer and Newsmonger, being (as yet) sound both in body and mind, do this fifteenth day of April, in the year of our Lord, seventeen hundred and ninety seven, make, declare, and publish, this my last will and testament, in manner, form, and substance, to wit: $:^{31}$

Here there follows a lengthy list of heirs, each jabbed with his quill, the twenty-third of whom is:

it was a weakness of the Constitution that they represented state government, not the people.

${ }^{29}$ Cole, p. 302.

${ }^{30}$ Cobbett, Political Censor, January I797, pp. I4-I 5.

${ }^{31}$ Cobbett, Political Censor, March 1797, in Porcupine's Works, Vol. 5, p. 107. "Since I took up the calling that I now follow, I have received forty threatening letters; some talk of fisticuffs, others of kicks, but for the greater part menace me with outright murder. . . . Under these terrific circumstances, it is impossible that Death should not stare me in the face...." 
Tom Paine, the author of Common Sense, the Rights of Man, Age of Reason, and a Letter to General Washington, (to whom) I bequeath a strong hempen collar, as the only legacy I can think of that is worthy of him, as well as best adapted to render his death in some measure as infamous as his life; and I do hereby direct and order my executors to send it to him by the first safe conveyance, with my compliments, and request that he will make use of it without delay, that the national razor may not be disgraced by the head of such a monster. ${ }^{32}$

Paine having eluded the guillotine and failing to die a natural death as a result of his condition of imprisonment, Cobbett bequeathed him an alternative means to end his life. Cobbett wrote to effect Paine's literary death, but clearly desired his literal death.

Cobbett's popularity increased on both sides of the Atlantic where his publications were quickly reprinted. The methods he used, though they seem reprehensible to modern readers, were an accepted style of journalism which Cobbett's talent brought to its height of effectiveness. But he fell afoul of the law in I 799, when after having won a case of libel brought against him by the Spanish Ambassador, he was again charged, this time by Dr. Benjamin Rush, an eminent physician. Cobbett lost as a result of the pressure brought by Judge Thomas M'Kean, Rush's political ally. ${ }^{33}$ Cobbett had appealed to have his case heard in a Federal Court, which was his prerogative as an alien, but M'Kean blocked him and the outcome was prejudiced against him in Pennsylvania. Cobbett quickly moved to New York where he established the Rush-Light, "intended to assist the publick view, in the inspecting of various tenebrious objects. ..." But M'Kean's decision not to grant his petition to have the case heard in a federal court, prompted Cobbett once again to bring Paine into the dispute.

Such is the manner in which written constitutions are observed. That indefatigable constitution grinder Tom Paine, told his silly partisans in England, that they had no constitution at all, and this he represented as a most insupportable grievance. Now, in America, it is not so. If you ask an American citizen,

\footnotetext{
32 Ibid., p. 114.

${ }^{33}$ Both M'Kean and Rush had signed the Articles of Confederation and Rush had been a signer of the Declaration of Independence. M'Kean's daughter was married to the Spanish Ambassador who first sued Cobbett for libel.

${ }^{34}$ Cobbett, Rush-Light, No. I, February I 5, I 800, p. 3.
} 
whether a certain procedure be constitutional, or not, he takes down the book from the shelf, opens it, turns to the article that treats on the subject in question, and gives you an answer in a moment. Very true, Thomas; so you see I took down my copy of the constitution and of the constitutional law, I turned to the article and the section that treated of the subject in question, and I prayed the judges to grant my petition accordingly, but the judges laughed at me and the constitution too. ${ }^{35}$

Paine, three thousand miles away, was the foil for Cobbett's arguments even in this dispute between Cobbett and Rush. Cobbett engaged him in one-sided conversations and often addressed him by his Christian name, Thomas or Tom. This was unusual for Cobbett. His subjects were usually given derogatory appellations or referred to by their family names: occasionally in a satiric manner, the professional title "doctor" or "parson" was used, as with Franklin, Priestley, Malthus, or Rush. Of course, he did this with Paine, too. But with Paine, Cobbett adopted a familiar style which he never used toward other pamphleteers. And yet, Cobbett exhibited a patronizing tone, often taking the older man, Paine, to task for his words. Cobbett seemed to recognize Paine as an equal, a compliment he extended to no other contemporary.

Cobbett left New York in I 800, to return to England where his reputation as a pamphleteer had preceded him. He was warmly welcomed by Prime Minister William Pitt for his defence of Britain against all detractors, not the least of whom was Paine. ${ }^{36}$

Paine, of course, was an internationally known and controversial figure. Although released from prison in 1793 , Paine was unable to leave France because of the threat of capture by the British. It was a time when the tide of his fortunes was at its lowest ebb. Still, he provided interesting copy for Cobbett's pen.

Paine returned to the United States in I 802. One of the first acts of Thomas Jefferson's first administration was to make the arrangements for his passage. His health was failing and he left his New Rochelle farm to avoid the abuse of his neighbors, taking up residence with Madame Bonneville and her children in New York until his death in June of 1809 . He continued to write but his failing health and lack of popularity discouraged any major work.

${ }^{35}$ Cobbett, Rush-Light, No. 4, March 31, I800, p. 173.

36. Osborne, p. 2 x. 
Cobbett busied himself in England and by 1802 had established the Political Register, which was to be published almost continuously until his death in 1835 . Through the Political Register, Cobbett began to examine and assault the policies of the Tory ministries of Pitt and Addington. This led to his imprisonment in $18 \mathrm{IO}$ for seditious libel against the government. While thus incarcerated in the State Prison at Newgate, he published a series of letters dealing with the financial system of England, the last of which were published after his release in $\mathbf{I} 8 \mathrm{I} 2$.

In 18 I 7 , Cobbett again fled England, the most widely read and successful pamphleteer of his day. Before leaving for America, he published in pamphlet form, his Paper Against Gold, a compilation of the thirty-two public letters which rest heavily on Paine's arguments.

Gentlemen, do you remember the writings of Paine? Do you remember the Rights of Man for the writing of which the author was prosecuted by the then Attorney General who is now the Lord Chancellor? . . . . Paine said, that the existence of the government depended upon the existence of the bank-notes; and that the question was not how long the British government would stand; but how long the Funding System would last. ${ }^{37}$

This quotation, of course, does not appear in the Rights of Man, so Cobbett was obviously writing from memory in prison, without the Rights before him as a reference. It is from Paine's Decline and Fall of the British System of Finance written in France in I794. The previous quotation appeared in the fifth letter of the Paper Against Gold. In the twenty-fifth, he claimed that he first read Paine's work on English finance in $\mathrm{I} 803$.

In 1803 , when there was much apprehension of invasion, and when great complaints were made of the scarcity of change, I began to read some books on the subject; and, after reading several without coming to any thing like a clear notion of the real state of our currency, I took up the essay of Paine. Here I saw to the bottom at once. Here was no bubble, no mud to

${ }^{37}$ Cobbett, Letter V, Newgate, September 17, 1810, in Paper Against Gold; or The History and Mystery of the Bank of England, of the debt, of the stocks, of the sinking fund, and of all the other tricks and connivances, carried on by means of paper money (London, I 8 I 7 ), p. 45. 
obstruct my view: the stream was clear and strong: I saw the whole matter in its true light. ... ${ }^{38}$

It is this reference to his conversion in I 803 , that is usually accepted as the turning point in Cobbett's opinion of Paine. A comparison between the fifth and the twenty-fifth letters shows he had since corrected the source of Paine's arguments. Cobbett could remember in I 8 Io the arguments Paine used seven years after having read them, but could not accurately remember the source. Yet, obviously, in 1803 , when searching for an answer to the financial problems then affecting Britain, he had recalled a work of Paine's he had read seven years before and turned to it in desperation.

Thus it appears his opinion of Paine's work, at least on this subject, changed at least seven and possibly fourteen years before the letters were written. Yet, it was not until after Paine's death in I 809 that he publicly acknowledged that transformation. Cobbett's account in I 8 I I of this "first" encounter with Paine's "Decline ..." reads: "By accident $I$ possess a copy that I brought from America, but which I never read till after my return to England." ${ }^{39}$ Evidently Cobbett had forgotten, or wished not publicly to recall, that in his scurrilous biography of December I 796, he admitted having read it.

$\mathrm{He}$, or someone in his name, has lately written a work, entitled, the Decline and Fall of the British System of Finance, of which it is quite enough to say, that it is of equal merit with the rest of his writings. All his predictions have hitherto remained unfulfilled, and those contained in the last effort of his malice will share the same fate. It is extremely favourable for the British bank-notes, that he who doubts of their solidity will not believe in the Bible. ${ }^{40}$

That he did indeed read it, or at least was aware, not only of its subject matter, but the prophecies contained therein, seem clear from his attack at that time. The following excerpt from Letter XXV is ironic in view of Cobbett's hand in the early attacks on Paine.

How happy would it have been for this nation, if the opinions of Mr. Paine touching this subject, had produced at that time, their wished for effects! No man in England dared to publish

${ }^{38}$ Ibid., Letter XXV, September 5, I 8 I I, p. 256.

${ }^{39}$ Ibid., p. 256.

40 Cobbett, Political Censor, December I797, p. 59. 
his work. Any man who had published it would have been punished as a seditious libeller. Yet, in my opinion does that work; that little work, in the space of twenty-five pages, convey more useful knowledge upon this subject, and discover infinitely greater depth of thought and general powers of mind, than are to be found in all the pamphlets of the three-score and two financiers. ${ }^{41}$

Curiously, it was Cobbett's pamphlets, written in America from I 796 to I 800 and republished in Britain, which supported the government's position and helped to suppress Paine's opinions on the government's monetary policy.

After reading, as he says, all the financiers had to say on the subject in 1803 , Cobbett turned to Paine. The incorrect reference to Rights of Man in the fifth letter illustrates that he remembered reading a clear statement on the subject in Paine but had forgotten in which work it appeared. Paine's clarity of argument must have been in Cobbett's mind from I 796. Yet, he admits having read several others in 1803 , hoping to find one who could make clear to him the subject with which he wished to deal but felt incompetent. Reluctantly, he turned to Paine, who showed the way as no one else could. Unable to find any other discussion of the subject which he could grasp, and unwilling to use Paine's ideas, he forebore giving Paine credit while he lived. Dead, he was willing to heap praise upon him and use him for his own ends. (It is of interest that no mention was made of Paine's passing in the Political Register in I 809, the year of his death.)

In America in 1817 , Cobbett took up residence on Long Island, maintaining his contact with England by writing articles for publication in his Political Register. While there, he announced his intention of writing a biography of Paine.

He tells us:

I resolved, while in America, to write an account of the Life, Labour, and death of that famous Englishman, Thomas Paine; and, perhaps, to collect and republish the whole of his writings complete in a cheap form, and with some explanatory notes to the 'Rights of Man' particularly. I had within my reach all the means of correct information. There was only Long Island ${ }^{41}$ Cobbett, Letter XXV, September 5, I8I I, Paper A gainst Gold, p. 332. 
Sound and a few miles of land between me and the spot where he died. Justice to his memory, justice to the cause of freedom, justice to the country that gave him birth, justice to his friends on both sides of the Atlantic, demanded at my hands an earnest endeavor to perform this task in a manner worthy of the subject. $^{42}$

Justice from whom? Cobbett had been his most vociferous and energetic enemy, the man who had dedicated four years of his press career in leading the assault on Paine and his work. Paine never deigned to answer but lived in quiet obscurity publishing little after his return to America, and that mostly advice to his fellow countrymen, except for objective pieces in defence of an agricultural society and religion.

In America, Cobbett collected what materials he could from Madame Bonneville, Paine's housekeeper, and his original biographical draft is extant. ${ }^{43}$ He went to great lengths to disprove the rumor that Paine had returned to the Quakerism of his youth. Cobbett related,

... a Quaker at New York, named Charles Collins, made many applications for an interview with me, which at last, he obtained. I found that his object was to persuade me that Paine had recanted. I laughed at him and sent him away. . . . I made him at last put down the full name and the address of the informer, 'Mary Hinsdale, No. ro Albany Street, New York. ${ }^{\text {,4 }}$

Cobbett then searched for and cross-examined the woman. "The result was that it was so long ago, that she could not speak positively: and that she had never given 'friend Charley' authority to say anything about the matter in her name. ${ }^{35}$

Yet Cobbett had substantial testimony concerning Paine's beliefs at the end of his life in addition to the many clarifications and defences Paine wrote concerning his religious position. Paine ". . when pressed on his death-bed to confess faith in Christ as his Savior ... replied, 'I do not wish to believe anything on that subject. ... I have lived an honest and useful life to mankind; my time has been spent

\footnotetext{
${ }^{42}$ Cobbett, Progress of a Plough-Boy, pp. 165-166.

${ }^{43}$ Conway, Vol. II, Appendix A, pp. 433-459.

${ }^{44}$ Cobbett, Progress of a Plough-Boy, p. 166.

${ }^{45}$ Ibid., p. I 68.
} 
in doing good, . . . and I die in perfect composure and resignation to the will of my creator.' "\$6

The Quakers refusing to admit his body to their burial grounds, Paine wrote in his will (January I 809), "... I desire to be buried on my own farm at New Rochelle. The place where I am to be buried, to be a square of twelve feet, to be enclosed with rows of trees, and a stone or post and rail fence, with a headstone with my name and age engraved upon it, author of 'Common Sense.' "47 Madame Bonneville, the executrix of his will, promised Paine that his wishes would be carried out. Yet Paine was fearful lest ". . . the farm will be sold, and they will dig my bones up before they be half rotten." ${ }^{\prime 8}$ Madame Bonneville testified, "Many persons have taken away pieces of the tombstone and of the trees, in memory of the deceased; foreigners especially have been eager to obtain these memorials. . . . Verses in honor of Paine have been written on the head stone." this simple but honored place that Cobbett surreptitiously snatched his body. ${ }^{50}$ All of this testimony concerning Paine's last years, his will, burial and Madame Bonneville's statements were in Cobbett's possession at the time he disinterred the body in I 8 I 9 against Paine's express fears. Cobbett publicly announced,

I have done myself the honor to disinter his bones. I have removed them from New Rochelle. I have dug them up; they are now on their way to England. When I myself return, I shall cause them to speak the common sense of the great man; I shall gather together the people of Liverpool and Manchester in one assembly with those of London, and those bones will effect the reformation of England in Church and State. ${ }^{\mathbf{1 1}}$

In this statement, taken as a whole, it appears that Paine's bones could be of service to Cobbett. Whether or not Cobbett would have undertaken such an "honor" had Paine rejected Deism in his last hours, we will never know. Had the plan to erect a memorial been

${ }^{46}$ Thomas Paine in The Radical Tradition: Tom Paine to Lloyd George, by John W. Derry (London, 1967), p. 45 .

${ }^{47}$ Thomas Paine in Dos Passos, p. 159.

48 Thomas Paine in Man of Reason-The Life of Thomas Paine, by Alfred Owen Aldridge (New York, 1959), p. 315.

${ }^{49}$ Madame Bonneville in Conway, Vol. II, Appendix A, p. 455.

${ }^{50}$ Conway, Vol. II, p. 428. Paine's grave was opened in the dead of night without official permission by workmen hired by Cobbett, who supervised the job.

${ }^{51}$ Conway, Vol. II, p. 427. 
effectuated, Cobbett's motives would be of little consequence. But in light of the fact that Cobbett's political designs for the memorial were not accomplished, it becomes significant that, lacking the funds and support of public opinion to establish a 'suitable' interment, the remains of Paine were left to languish in Cobbett's possession, unburied. Clearly, Cobbett's intention was a wholly selfish one. And his public protestations of veneration for Paine were a political expedient to win the support of the reform movement in Britain.

The "bones" controversy raised a storm in America and in England. Cobbett was attacked in the press but received some much needed, albeit unfavorable publicity. He had been removed by time and distance from the political scene of action during a period of great popular unrest. Attention was now focused on him as he attempted to raise the funds necessary to have Paine reinterred in a suitable fashion. ${ }^{52}$

Cobbett was tireless in his work toward reform of the government and was sent to Commons in I 832 following the passage of the first Reform Act.

On his deathbed in 1835 , Cobbett had no thought of Paine's remains. It mattered not "whether his carcass is at last to be suffered to rot on the earth, or to be dried in the air" and it was of "little consequence ... whether his carcass be under ground." Cobbett's death was not sudden. He had sufficient time to put his own affairs in order. But he made no attempt to bury Paine at his own expense.

Though Cobbett's words have been used in an attempt to illuminate his relationship to Paine, clearly there is more here than those words convey. So often Cobbett's words are contradictory that it is too simplistic to state that in 1803 he read and appreciated Paine's thoughts on the finances and became his disciple. Nor is it reasonable under the circumstances to believe that Cobbett was driven by a respect for Paine or a desire to do justice to his memory. This leaves no explanation of his callous disregard for Paine's wishes or for simple Christian practice.

In the chronology of Cobbett's preoccupation with Paine, it appears that in 1792 he read the Rights of Man Part $I$ and was so impressed with it that he turned to republicanism and after a brief

52 Huish, a contemporary of Cobbett and his earliest, though often inaccurate, biographer, claimed that Cobbett offered rings for sale, containing a lock of Paine's hair. Whether or not he did make such an attempt at raising money for the project, no rings were ordered or made. See Huish, Vol. II, Pp. 298-299. 
sojourn in France (which he admitted gave him the opportunity to learn French) emigrated to the United States, "desirous to become the citizen of a free state." In May of I 796, after taking up a career as a political writer, he printed an epitaph of Paine while he was still alive and declared him dead politically; in December of 1796 he published a biography commending him to a non-grave, leaving behind only a legacy of infamy; in I 797 he suggested Paine should have gladly gone to the guillotine instead of seeking to avoid it with American help; in April of 1797 he willed him a noose with which to hang himself; and from I 796 to I 800 he concentrated his journalistic efforts on destroying Paine's political life as a pamphleteer.

On his return to England in I 800 the pattern changed. Cobbett's political opinions swung toward reform and in 1803 he read Paine's paper on finance and changed his opinion of him again, though it has been shown that in fact he had read it earlier ( 1796 ) and went to it only when no other writer on the subject could express clearly what he wanted to know. In I 809 he ignored Paine's death in his Political Register. In I 8 Io he praised Paine's work publicly, but only after Paine was dead and buried. In I 8 I I he publicly gave the reason for his conversion by way of explaining his use of Paine's arguments to lend weight to his discussion of the finances, which admittedly confounded him. In I 8 I 8 he announced a new biography which, though he wrote prolifically for the next seventeen years, he never found time to complete. (In all fairness it should be noted that he did not find time to write his own projected autobiography, either. But he did pen a biography of Andrew Jackson in I 834 based on J. H. Eaton's work.) In I 8 I 9 he disinterred Paine's body, against Paine's express wishes, which he knew; thereby profitting from the much needed publicity and with the express purpose of using it as a rallying point for his own political objectives.

What confuses the issue is that throughout the period from $\mathrm{I} 8 \mathrm{IO}$ to $\mathrm{r} 835$, Cobbett could not heap enough public acclaim on Paine's head. ${ }^{53}$ And it has led to the assumption that Cobbett had undergone a change of opinion concerning Paine; a change which caused him to

\footnotetext{
${ }^{53}$ Cobbett in Conway, p. 58. "As my Lord Grenville introduced the name of Burke, suffer me ... to introduce that of a man who put this Burke to shame, who drove him off the public stage to seek shelter in the pension. . . Mr. Paine ... was the real cause of the Revolution in America; for though the nature of the cause of America was such as I have before described it; though the principles were firm in the minds of the people of that country; still, it was Mr. Paine, and Mr. Paine alone, who brought those principles into action."
} 
become, not a political Painite, but a true admirer of the great political philosopher.

If Cobbett meant to undo the injustice he had done Paine's reputation in the eighteenth century, he accomplished his purpose; for he reawakened the interest which brought a renewed appreciation for "Old Common Sense." Though he restored Paine's literary reputation (which it is to be supposed would have occurred in any event as a consequence of the quality and effectiveness of his political philosophy) his actions were of little value except to align him with the political forces which were to his advantage once he had determined to oppose the corruption of the British government. But, the fact remains that Paine alive received no quarter from Cobbett; dead, Cobbett could use the stature of his name, his arguments and even his remains.

If Cobbett was prompted to do honor to Paine's memory, his actions are opposed to any rational argument that can be given for leaving his bones unburied. Had Cobbett been an atheist, his disregard for the basic amenities of Christian behavior in such matters might be argued. But Cobbett was a life-long Anglican. As John W. Derry points out, "In religious matters his home was undemonstrably orthodox. Cobbett was bred up an Anglican, which may partly explain his hostility towards Dissenters, and though he never showed any taste for theological speculation he remained a life-long member of the Church of England-'the more so, perhaps,' as Cobbett said, 'as it bears the name of my country.' "'54

Osborne clarifies Cobbett's religious attitude.

There was nothing of the metaphysician or mystic about Cobbett. Religion, as far as he was concerned, was useful in proportion to its positive effect upon a person's conduct, and conduct, not faith, was the measure of the intensity of religious feeling. For the forms and rituals of religion Cobbett had only contempt.... ${ }^{55}$

This casual attitude toward religious practice is an effective argument explaining Cobbett's failure to make any arrangements for Paine's reburial. Yet, Cobbett held Paine's remains for over fifteen years which suggests a callous disregard and insensitivity toward both public and private opinion on the disposition of the dead. $\mathrm{He}$

${ }^{54}$ Derry, p. 48.

55 Osborne, p. I 96. 
was forced to acclaim Paine's writing publicly in order to use his arguments. But Cobbett perpetrated the final indignity on Paine's memory by depriving him of even a simple burial place.

Cobbett, his biographers agree, was a monumental egotist who gave no quarter to his rivals. In the field of pamphleteering, Paine was his greatest rival for historic eminence. Attack was Cobbett's method and his penchant for revenge revealed itself throughout his public career. This aspect of his character gives some meaning to his treatment of Paine's remains. Cobbett never gave in to a rival or forgave an enemy. Cobbett, like Creon in Sophocles' "Antigone," pursued his enemy beyond death. And Paine, like Polyneices, was to suffer the last great indignity at the hands of William Cobbett, who claimed to seek justice for the "truly philosophical politician." Any argument that suggests William Cobbett was at any time moved by true admiration for Thomas Paine should be reexamined. For Cobbett, like Creon, believed, "An enemy is an enemy, even dead."

The last word has not yet been written on the remains of Tom Paine. Moncure Daniel Conway offered the evidence that:

In 1836 the bones passed with Cobbett's effects into the hands of a Receiver (West) ... they were kept by an old day labourer until I 844, when they passed to B. Tilley, I3 Bedford Square, London, a furniture dealer. In I 849 the empty coffin was in possession of J. Chennell, Guildford. . . . In I 854, Rev. R. Ainslie (Unitarian) told E. Truelove that he owned "the skull and right hand of Thomas Paine," but evaded subsequent inquiries.... ${ }^{56}$

The search had seemingly ended for Conway in a blind alley. But in July of 1976, at Tivoli, New York, about 60 miles north of New Rochelle, the site where Paine had originally been buried, a stone marker inscribed,

In Memory of Thomas Paine who was born at Thetford, England January 29, I 737

Died at New York June 8, 1809

Aged 72 years 4 months and 9 days $^{57}$

${ }^{56}$ Conway, Vol. II, p. 427.

${ }^{57}$ New York Times, July 19, 1976, p. 42. 
was unearthed. The question remains whether investigation will reveal that Paine found a final resting place in America. Whether some traveling fellow countryman came upon the bones for sale in a dingy side street shop and performed the charitable task of returning them to a final resting place has still to be explored. 